\title{
An Empirical Study of Spirituality in the Workplace
}

\author{
Effulgence \\ Vol. 16 No. 1 (Special Issue 2) \\ January - June, 2018 \\ Rukmini Devi Institute of Advanced Studies \\ E-mail : effulgence@rdias.ac.in, Website : www.rdias.ac.in \\ http://effulgence.rdias.ac.in/user/default.aspx \\ https:/ / dx.doi.org/10.33601/effulgence.rdias/v16/iSpl2/2018/1-13
}

\section{Dr. Urvashi Ghai ${ }^{1}$ \\ Dr. Divya Mohan²}

\begin{abstract}
In the field of Human resource management, the involvement of spirituality is only increasing. For recent day's HR challenges everyone from academicians to practitioners are favoring spirituality to solve problems. One can see the negative impacts of these HR related problems on every industry and the big Indian Insurance industry is also no different. The presented paper is mainly aimed to focus upon specific HR issues of Indian Insurance companies and how workplace spirituality affects them. Among all the HR issues such as work motivation, employee engagement and managerial effectiveness are the major ones where companies need improvement and the spirit of Spirituality at work can do the task for them. This research paper also acknowledges the gaps between conceptual and factual usage of the workplace spirituality concept. By successfully adding one more dimension (karma capital) of Indian spiritual values, this paper supplements literature here. Moreover, this paper is one of the pioneer studies that is based upon necessary condition analysis to explore workplace spirituality. Workplace spirituality is an essential principle of employee engagement, motivation and managerial effectiveness and their relationship is further examined by correlation matrix and regression analysis.
\end{abstract}

Keywords: Work Motivation, Employee Engagement and Karma Capital of Indian spiritual values.

\section{INTRODUCTION}

$\mathrm{T}$ he service industry has expanded exponentially. Insurance industry in India has also grown remarkably and the penetration to different income group also seems to grow rapidly. This is the wellknown fact that all service industries require human resource department. This is an era where the competition is so intense especially in the insurance industry where competitive advantage can be gained through human resources development. This is the reason that more of insurance companies started to understand the importance of Human Resource and have started using it for management practices. In this competitive business environment bring out the way to ensure success is a challenge, hence focusing on motivation of the employees to increase productivity side is quite effective way. This will not only benefit the organisation, but also the employee. Defining HR policies in an organisation and its growth prospects is key function which needs deep understanding of its employees need. Employees can 
get benefit from HR policies in many ways like better compensation, career growth, Training and development programmes and various other benefits. All of this will lead to better job satisfaction and employees' stability.

\section{Benefits of HR policies}

High performance work system Is believed to have a positive impact on the employees as they inspire, motivate and increase the trust on the organisation which can turn into a favorable effect for the organisation. HPWS body is designed by arranging human resources in a lucid manner, then they choose good influence from higher kill execution through comparing positive effect on employees' attitude, motivational level and prosperity. Many of the researchers have concluded that there is a positive relationship between HWPS and job satisfaction of employees. Apart from this few more factors which are responsible for this relationship is employs fulfilment, trust and responsibility on the Administration and faith. With increase in the level of employee satisfaction, trust and responsibility also increases ability motivation opportunity a $\mathrm{MO}$ model of human resources management clearly defines that how the Employees are benefited by HWPS's. HWTS clearly influences employees in a great way this is defined clearly by AMO IN the following way

- Contemporary SWP can be said that it is works to prepare employees for better career positions and broadening job opportunities. Employee's capability and ability play out employments in an effective way and show more activity work.

- HWTS acts as an administrative body which helps in making decentralised decisions which would be fair and equitable to all employees. This is the major reason for why the employees could use the aptitude capabilities in a better way.

- Planning the progress decentralisation imaginative crew and solidarity helps employees to amplify their through unique intrusion in place. This type of solidarity helps the employees to articulate their creativity in a way which can enhance the experience of importance at work.

The literal meaning of spirituality has changed these days. Spirituality now means elite work framework. In order to crack the modern-Day human resource challenge like inspiration, engagement, corruption, motivation, stress etc. both of the academicians and exports depend upon deep sense of being able to break down In order to get better industrial results.

Due to modernisation work and relationship style these days have definitely changed. Most recent innovation and methods have changed the work culture and atmosphere. Every one of these changes and improvement have changed the harmony of relationship between workers, Association and society. Development realism and Blind raise for benefit and wealth has circulated or shared advantages relationship between these three Mainstays of the country. Along with all these advancements and developments spirituality carries its own important role to be played in the industry. Spirituality has its own importance on all three levels organisational level, the socialite level and at employee's level. Insurance industry can also seek to resolve their workplace spirituality problem by having proper resource management programs.

\section{Workplace spirituality - A New Era of effective HRM}

The notoriety of idea of spirituality at workplace is expanding exponentially in the field of human assets administration. With growing number of organisations in the industry it has become very important to improve the working environment for the employees. It has been reported by many researchers that workplace spirituality is accounted for the out worldly existence which should be related with larger amount of hierarchical effectiveness with equal amount of rate of return. 
Karen K. Said "spirituality leads to increased physical and mental health of employees it also results in advanced personal growth and enhanced sense of self-worth."

Spirituality at work place helps in ploy to have a sense of being able to create their performance level according to their potential. Mohamed in 2004 stated that "spirituality makes unemployed more tolerant for work failure and listen to stress". Apart from this many of the other research scholars have started to explore the motivational aspects which playing important role in both please quality these days. According to the research feet is research scholars are you shape golf was also between employees having motivation to excel and the desire to utilise their greatest potential among the employees Who are willing to stay with the full for longer period of time. Expanding number of companies in the industry are searching for various approaches to persuade the world. While the researchers these days are still hunting to search for a way to encounter workplace spirituality. Employees desire to have spirituality please is secured by a secret key to the work efficiency. Those these two issues are associated with the zeal to perform employees have at office but according to the research done on board please spirituality at the motivation needs to be developed independently. The numerous studies have been done to understand the interconnectedness of both play spirituality and the motivation level of employees but it hardly tries to conclude. Ming-chia in 2012 Concluded that not much studies have been done on this field. There can be assorted reasons for less enthusiasm for research on this field

1. Spirituality is viewed as individual and private issue in India and workplace spirituality is an otherworldly existence which is generally not even rehearsed in the Indian companies.

2. For going to the accessibility of various religions and six and lines of confidence, researchers are not consistent about meaning of the term spirituality.

3. Evaluation of spirituality esteems and spirituality process is challenging task for researchers.

4. At long last Indian work inspirations and workplace spirituality of employees are viewed as absolutely inverted criteria.

The major question is that the, the relationship between these two has not been efficiency searched by Indian industry yet. The current investigation is one of the pioneers which works in this field and makes use of important conduction examination to land up on any persuading result. With this paper, we will be trying to augment current available literatures on the existence of spirituality in the industry by adding information from profound sagas Bhagwat Gita, KenaUpanisad and Astavakra Gita.

\section{Literature Review}

Zohar and Marshall in 2000 Defined spirituality an intelligence. According to them, spirituality is also related to hyper thinking, contextualising and transformative intelligence Spirituality has been characterised in number of ways:

- State of mind

- Qualities and conviction framework

- The knowledge

- Advancement in the line

- A way to approach and associate with innersuperpower and experience.

In this way spirituality offers approach to IQIntelligence quotient and emotional quotient. Excepting spirituality at work please also means that Roy is waiting now will have the able to rise above the physical and material world. Spirituality also incorporates experienced and uplifted condition of awareness. Wilber in 2004 said "that the spirituality depicts highest level of any development line"

Kumar and neck in 2002 said "workplace spirituality intrudes or search for meaning and fulfilment and it is also related to feeling of being interconnected work with one another also" Mitra and dental in 
1999 siad that "spirituality could be defined as ability to get connected with once complete self as well as with others and the universe". Ashmos and Duchon in 2000 also identified spirituality dimensions as "meaning, purpose, and a sense of community connection to others". Other research scholars said that it is the feeling of superiority, completeness and joy. Ashforth and Pratt in 2010 stated "Please spirituality has three major facets transcendence of self, who listen and harmony growth". Pefter in 2010 elaborated the basic dimensions of workplace spirituality "interesting work and completeness and mastery, meaningful work, positive social relations with co-workers and the ability to relieve an integrated life".McCornick said in 1994 "Meditative work as experience of being totally absorbed in work and thus loosing sense of self". Here this means that the employs the one with work and there can be no detachment which implies between the employer and the work. The employees become the one with work and there can be no detachment which implies between the employer and their work. Meditative is a more profound view point of spirituality, which means that complete sense of being into work. Feeling of community has teamed up with interconnectedness and those employees who work independently. Morgan in 1993 added one more idea to make the people feel more for the community. In 2005 it was reported by a researcher that the authenticity of work in walls intelligence and transparency at work place. AccuracyIs usually said as synchronisation between employee's actions and behaviour with disguised social esteems and convictions. In bhagwadgita, loardkrishna introduces the idea of lokasangraha. This idea indulges to benefit all the people of the universe. According to the literature of current Administration, lokasangraha is estimated in terms of transcendence. The word transcendence means "connection to something greater then oneself".

\section{Employee Engagement}

Various practitioners, scholars and researchers have featured the level of work engagement of employs at work these days. With this they have come up with a new term called "engagement gap". Workplace spirituality has advanced, as a compelling answer to manage deficiency of employee engagement. Various organisations have come up together to find a solution to create a spiritual place, where an employee can work with their complete potential. The level of engagement of employs at work is clearly related to their spirit at work. The level of engagement of employees at workplace is directly related to their feeling of completeness and job satisfaction. The literal meaning of spirituality is the sense of completeness. Employee engagement incorporates the synchronous setup of all parts of one performance i.e. Cognitive, physical and emotional. This means an idol spiritual workplace should have complete employee's involvement. Having spirituality at work place gives freedom to employees to express various facets about them self which is not just physical, but intellectual as well. According to Indian spiritual values, it promotes employees to have complete dedication and responsibility for the organisation. A company cannot grow without their employs dedication so devotion for the organisation brings confidence and faith for each other. There are various teachings which shows the incredible significance and the importance of employees, to work towards the organisational goals and ignore any kind of personal discrepancies among themselves. Bhagwat Gita also states the same, that employee must work towards benefit of the company and abandon any kind of personal differences. This kind of $t$ theory brings a common linkage between the employees and their workplace spirituality.

\section{Work Motivation}

Tongo in 2016 stated that "researchers of recent times have started to formulate contemporary theories that addresses the spiritual needs of employees at work place". There is an idea that employees are inspired by their egocentric requirement which have crucial impact of inspiring strategies by supervisors these days. Some of the 
incidents happening these days like corruption and assignment shows that the activity done by the official these days impacted by individualistic and egoistic needs. This process of self-glorification and prosperity of different partners like customers and society is not much important. In the process of Yarkhill decision making it is likely that the decisions would be affected by the eagerness of top level management system. These kinds of scenarios can be dealt with by rehearsing spirituality at our work place. As far as the Indian Sagar's are concerned like Bhagwat Gita, which is considered as in is which can provide motivation. In lot Krishna motivated Arjuna to stand out among the most imperative wars of Indian history. Verse 2.38 in Bhagwat Gita states that "One must work with hundred percent commitment without fear of win or lose, profit or loss and happiness or sorrow".

There is conceivable relationship among guest spirituality motivation and this is proved by the spiritual inferences of the Indian society. In this paper we will be trying to measure the connection among spirituality and motivation level of an employee.

\section{Objectives}

Right off the bat the general population tends to investigate the status of work place spirituality, engagement of employee at workplace, inspiration of their work and supervisor viability in Indian insurance agencies. Also, this research investigates the connection between Three employee level results i.e. worker engagement, inspiration and the role played by management

\section{Research Design}

The investigation of this research is done in workplaces of insurance agency from NCR region. In this way arbitrary testing has been utilized to get the result as accurate as possible. This research depends on the sampling of 100 representatives working in different insurance agency. The respondents' demography, for example, age, Gender and work encounters instructive capability. Stop be estimated Bulkeley most profound sense of being the assistance of scale created by Monday. Scale depends on the builds of otherworldly existence; swadharma, legitimacy, neighborhood Sangra her and feeling of group. The frightening has been altered by including one extra build that is Karma capital.

The sample survey has been based on the following two criteria i.e., Age and Experienced wise:

\section{Table 1 : Age wise criteria}

\begin{tabular}{|l|l|l|}
\hline S.no. & Age & Percentage \\
\hline 1 & Less than 25 years & 23 \\
\hline 2 & $26-35$ years & 59 \\
\hline 3 & $36-45$ years & 13 \\
\hline 4 & $46-55$ years & 2 \\
\hline 5 & 55 years till the age of retirement & 3 \\
\hline
\end{tabular}

Table 2 : Experienced wise criteria

\begin{tabular}{|l|l|l|}
\hline S.no. & Experience & Percentage \\
\hline 1 & Less than 5 years & 47 \\
\hline 2 & 6-10 years & 33 \\
\hline 3 & More than 10 years & 20 \\
\hline
\end{tabular}

Descriptive statistics of three variables of the research are motivation and engagement. Factor analysis has been applied to overcome the problem of severe multicollinearity through data reduction. Correlation matrix provides an insight into association of these variables towards probable association between two variable and on the other hand, regression supports in determine of dependent variable with help of independent variable. Regression analysis believes that each reason is sufficient to increase the outcome but none is necessary. In regression, causality is additive model and its relationship can be expressed as :

$\mathrm{Y}=\mathrm{a}+\mathrm{b} 1+\mathrm{b} 2 \mathrm{X} 2+\mathrm{b} 3 \mathrm{X} 3$

If value of one determinant is zero, the other will be reduced. This reduction in outcome could be compensated by increasing the values of other determinants. Thus, the regression analysis fails to 
predict the necessity condition of an independent variable. Analysis of necessity condition is used to explore the employee engagement and work motivation.
Findings: Exploration of three specific challenges of Indian insurance industry

Table 3 : Descriptive statistics of HR challenges in insurance companies

\begin{tabular}{|c|c|c|c|c|c|}
\hline HR Challenges & & N & Mean & SD & t-Value \\
\hline $\begin{array}{c}\text { Employee } \\
\text { engagement }\end{array}$ & 100 & 2.07 & 0.77 & 2.13 \\
\hline Work motivation & & 100 & 2.12 & 0.82 & 2.21 \\
\hline
\end{tabular}

Table one gives elaborated description of employee engagement work motivation and manage to effectiveness of employees working in Indian insurance companies.

Table 4 : Radiations in HR variables based on ownership of companies

\begin{tabular}{|c|c|c|c|c|}
\hline HR Variables & Public Sector & Private Sector & t-values & Significance \\
\hline $\begin{array}{c}\text { Employee } \\
\text { engagement }\end{array}$ & 2.11 & 1.87 & 2.23 & 0.32 \\
\hline Work motivation & 1.69 & 2.36 & 2.78 & 0.31 \\
\hline
\end{tabular}

Table 5 : Variations in HR variables based on nature of business insurance companies

\begin{tabular}{|c|c|c|c|c|}
\hline HR Variables & $\begin{array}{c}\text { General } \\
\text { Insurance }\end{array}$ & Life Insurance & t-Values & Significance \\
\hline $\begin{array}{c}\text { Employee } \\
\text { engagement }\end{array}$ & 2.03 & 2.10 & 9.03 & 8.11 \\
\hline Work motivation & 2.17 & 2.09 & 4.13 & 6.29 \\
\hline
\end{tabular}

Table 6 : Employee engagement and individual based variations

\begin{tabular}{|c|c|c|c|c|}
\hline Variable & Category & Mean & t-value & Significance \\
\hline \multirow[t]{2}{*}{ Gender } & Male & 1.92 & \multirow[t]{2}{*}{2.74} & \multirow[t]{2}{*}{0.01} \\
\hline & Female & 2.16 & & \\
\hline \multirow[t]{3}{*}{ Education } & Under Graduate & 2.25 & \multirow[t]{3}{*}{2.25} & \multirow[t]{3}{*}{0.27} \\
\hline & Graduate & 1.98 & & \\
\hline & Post-Graduate & 1.84 & & \\
\hline \multirow[t]{5}{*}{ Age } & Below 20 years & 1.63 & \multirow[t]{5}{*}{7.79} & \multirow[t]{5}{*}{2.83} \\
\hline & 21-30 years & 1.79 & & \\
\hline & $31-40$ years & 1.72 & & \\
\hline & $41-50$ years & 2.01 & & \\
\hline & Above 51 years & 2.16 & & \\
\hline \multirow[t]{3}{*}{ Experience } & $0-5$ years & 1.83 & \multirow[t]{3}{*}{8.02} & \multirow[t]{3}{*}{3.14} \\
\hline & 6-11 years & 2.03 & & \\
\hline & More than 12 years & 2.22 & & \\
\hline \multirow[t]{3}{*}{ Designation } & Managers & 2.14 & \multirow[t]{3}{*}{1.52} & \multirow[t]{3}{*}{0.00} \\
\hline & development officers & 1.83 & & \\
\hline & Supervisors & 2.06 & & \\
\hline
\end{tabular}


Table 6 represents detailed insights of demographic variations in the level of employee engagement. According to table, it can be said that with the mean value of 2.16, female employees are more engaged at workplaces as compared to their male counterparts (mean=1.92). This statistical difference in engagement level based upon gender specifies that management needs to adopt gender based strategies to aggravate employee engagement level. It is also noted that with higher educational qualifications, employee engagement decreases since post graduate employees with a mean value of 1.84 are observed least engaged with their firms. It could be a significant challenge for senior management to keep these highly qualified employees engaged. By assigning higher level of job responsibilities and delegation of authorities this problem can be much solved. Next significant effect on employee engagement is based upon their designation. Marketing personals are seen to be least engaged with their respective companies. Age and experience have not much effect on employee engagement, therefore they are not analysed in details.

Table 7 : Work Motivation and Individual based variations

\begin{tabular}{|c|c|c|c|c|}
\hline Variable & Category & Mean & t-value & Significance \\
\hline \multirow[t]{2}{*}{ Gender } & Male & 1.85 & \multirow[t]{2}{*}{1.72} & \multirow{2}{*}{0.07} \\
\hline & Female & 2.30 & & \\
\hline \multirow[t]{3}{*}{ Education } & Under Graduate & 2.47 & \multirow[t]{3}{*}{2.36} & \multirow[t]{3}{*}{0.35} \\
\hline & Graduate & 2.02 & & \\
\hline & Post-Graduate & 1.69 & & \\
\hline \multirow[t]{5}{*}{ Age } & Below 20 years & 2.38 & \multirow[t]{5}{*}{2.98} & \multirow[t]{5}{*}{0.41} \\
\hline & $21-30$ years & 2.20 & & \\
\hline & $31-40$ years & 2.12 & & \\
\hline & $41-50$ years & 2.05 & & \\
\hline & Above 51 years & 1.93 & & \\
\hline \multirow[t]{3}{*}{ Experience } & $0-5$ years & 2.18 & \multirow[t]{3}{*}{9.62} & \multirow[t]{3}{*}{1.19} \\
\hline & 6-11 years & 2.54 & & \\
\hline & More than 12 years & 1.86 & & \\
\hline \multirow{3}{*}{ Designation } & Managers & 2.12 & \multirow[t]{3}{*}{0.72} & \multirow[t]{3}{*}{0.01} \\
\hline & development officers & 2.31 & & \\
\hline & Supervisors & 1.82 & & \\
\hline
\end{tabular}

In table 7, there is a demographic variable based variation of motivation levels found in the employees of Indian Insurance companies. It is reported that female employees with mean value of 2.30 are more motivated than male employees (mean=1.85). Hence it can be said that female workers cause relatively less HR challenges than male employees. In the above table, it is also seen that motivation level decreases with age. The significant $\mathrm{T}$ - value for age establishes it as a significant moderator for workplace motivation. According to the researches, it is suggested to the
HR officials of insurance companies to institutionalize different norms of motivations that keep regulating the workplace motivation. Theories like job characteristics theory, social exchange theory, Ability-motivation-opportunity theory can be good help for HR practitioners. In comparison of the engagement table, marketing professionals are more motivated than administrative professionals. The reason behind this might be the system that gives monetary and non-monetary benefits in terms of incentives, premium commission, car and several other perks to employees. 
Table 8 : Exploration of workplace spirituality in Insurance companies

\begin{tabular}{|c|c|c|c|c|}
\hline $\begin{array}{c}\text { Constructs of Workplace } \\
\text { Spirituality }\end{array}$ & $\mathbf{N}$ & Mean & SD & T-value \\
\hline Swa- Dharama & 100 & 2.97 & 0.711 & 1.32 \\
\hline Karma Capital & 100 & 3.20 & 0.693 & 2.20 \\
\hline Sense of Community & 100 & 3.29 & 0.834 & 5.92 \\
\hline Lok- asangraha & 100 & 2.42 & 0.496 & 1.64 \\
\hline Authenticity & 100 & 2.18 & 0.595 & 2.25 \\
\hline $\begin{array}{c}\text { Overall Workplace } \\
\text { Spirituality }\end{array}$ & 100 & 2.81 & 0.432 & 2.62 \\
\hline
\end{tabular}

Table 8 highlights the level of workplace spirituality in Insurance companies. At a seven-point scale, the mean value of overall workplace spirituality in insurance companies is 2.81 . The $\mathrm{T}$-value points out that this mean value of 2.81 is significantly less than the mid value of seven-point scale. Findings states that spiritual practice like Yoga, meditation, pranayama, thought reconstruction etc. are good to improve spirituality at work. Swadharma, Karma Capital, Sense of Community, Lokasan-graha and Authenticity, these five are the constructs of overall workplace spirituality at work. Among these five, sense of community has highest mean value i.e. 3.29. Furthermore, $t$-value for this construe is also very less that is a good indication towards the healthy presence of sense of community among employees. On the other hand, Authenticity with a mean of 2.18 is a point where insurance companies need to work upon. Lack of transparency and accountability and absence of opaque style of management are the major reasons behind this.

Table 9 : Workplace spirituality variations depending upon company ownership

\begin{tabular}{|c|c|c|c|c|}
\hline $\begin{array}{c}\text { Constructs of Workplace } \\
\text { Spirituality }\end{array}$ & Public sector & Private sector & t-value & Sig. \\
\hline Swa- Dharama & 3.32 & 2.72 & 1.83 & 0.12 \\
\hline Karma Capital & 3.09 & 3.29 & 8.78 & 2.78 \\
\hline Sense of Community & 3.32 & 3.17 & 0.87 & 0.13 \\
\hline Lok- asangraha & 2.42 & 2.42 & 5.63 & 2.03 \\
\hline Authenticity & 1.90 & 2.29 & 1.22 & 0.48 \\
\hline $\begin{array}{c}\text { Overall Workplace } \\
\text { Spirituality }\end{array}$ & 2.82 & 2.74 & 9.42 & 2.43 \\
\hline
\end{tabular}

Table 9 shows the variations in workplace spirituality based upon the employees of private and public-sector insurance companies. Although there is no such variation in overall workplace spirituality. For Swadharma, mean value is comparatively higher for public sector employees which reflects that they consider their work as a service to humanity. Secondly, sense of humanity is also varying considerably among the employees of both sectors indicating that employees of public companies are more interconnected and related to each other than private sector employees. One can find a greater sense of togetherness and team spirit among government employees. Authenticity has significantly higher value for private employees as there is a common belief that work environment of private companies is more open and transparent. Rest two constructs Karma Capital and Lokasangraha have no significant impact. 
Table 10 : Nature of business and workplace spirituality

\begin{tabular}{|c|c|c|c|c|}
\hline $\begin{array}{c}\text { Constructs of Workplace } \\
\text { Spirituality }\end{array}$ & $\begin{array}{c}\text { General } \\
\text { Insurance }\end{array}$ & Life Insurance & t-value & Sig. \\
\hline Swa- Dharama & 3.32 & 2.72 & 1.83 & 0.12 \\
\hline Karma Capital & 3.09 & 3.29 & 8.78 & 2.78 \\
\hline Sense of Community & 3.32 & 3.17 & 0.87 & 0.13 \\
\hline Lok- asangraha & 2.42 & 2.42 & 5.63 & 2.03 \\
\hline Authenticity & 1.90 & 2.29 & 1.22 & 0.48 \\
\hline $\begin{array}{c}\text { Overall Workplace } \\
\text { Spirituality }\end{array}$ & 2.82 & 2.74 & 9.42 & 2.43 \\
\hline
\end{tabular}

According to the variations presented in table 10, it can be said that neither overall spirituality nor any of its construct vary significantly among the employees of general and life insurance companies.

Table 11 : Swadharma and Individual based variations

\begin{tabular}{|c|c|c|c|c|}
\hline Variable & Category & Mean & t-value & Significance \\
\hline \multirow[t]{2}{*}{ Gender } & Male & 2.63 & \multirow{2}{*}{1.94} & \multirow{2}{*}{0.35} \\
\hline & Female & 3.35 & & \\
\hline \multirow[t]{3}{*}{ Education } & Under Graduate & 2.96 & \multirow[t]{3}{*}{7.84} & \multirow[t]{3}{*}{4.95} \\
\hline & Graduate & 2.99 & & \\
\hline & Post-Graduate & 2.81 & & \\
\hline \multirow[t]{5}{*}{ Age } & Below 20 years & 2.64 & \multirow[t]{5}{*}{0.97} & \multirow[t]{5}{*}{0.00} \\
\hline & $21-30$ years & 2.77 & & \\
\hline & $31-40$ years & 2.79 & & \\
\hline & 41-50 years & 2.96 & & \\
\hline & Above 51 years & 3.17 & & \\
\hline \multirow[t]{3}{*}{ Experience } & $0-5$ years & 2.58 & \multirow[t]{3}{*}{2.74} & \multirow[t]{3}{*}{0.46} \\
\hline & 6-11 years & 2.80 & & \\
\hline & More than 12 years & 3.04 & & \\
\hline \multirow[t]{3}{*}{ Designation } & Managers & 2.91 & \multirow[t]{3}{*}{6.53} & \multirow[t]{3}{*}{5.93} \\
\hline & Development officers & 2.84 & & \\
\hline & Supervisors & 2.99 & & \\
\hline
\end{tabular}

Above table represents swadharma based variations among the employees of Indian Insurance companies. Gender, education, Age, Experience and designation are the five variables where variations are seen. Out of these 5 gender, age and experience are reported to cause major deviation among different categories. Female employees with a mean of 3.35 have higher value than male employees (mean $=2.63$ ). Findings found that with growing age and experience, desire for meaningful and meditative work also increases that further improves say of employees with organization.
Among all the constructs of workplace spirituality, Karma capital has special place in Indian culture. Here you will find a vast and diverse meaning of Karma that you won't find in other cultures. In table 10, there highlights the variables where karma capital deviations are seen. In insurance companies, female employees cause significantly higher than their male counterparts. The principle theory of Indian karma is one should work without fear of results, failure and success. And according to findings it has been noted that with age people believe and implement this karma theory in their work routines. Variations based upon educational qualification and designation are insignificant here. 
Table 12 : Karma Capital and Individual based variations

\begin{tabular}{|c|c|c|c|c|}
\hline Variable & Category & Mean & t-value & Significance \\
\hline \multirow[t]{2}{*}{ Gender } & Male & 3.03 & \multirow[t]{2}{*}{1.93} & \multirow[t]{2}{*}{0.38} \\
\hline & Female & 3.42 & & \\
\hline \multirow[t]{3}{*}{ Education } & Under Graduate & 2.86 & \multirow[t]{3}{*}{9.74} & \multirow[t]{3}{*}{2.83} \\
\hline & Graduate & 3.43 & & \\
\hline & Post-Graduate & 2.66 & & \\
\hline \multirow[t]{5}{*}{ Age } & Below 20 years & 3.42 & \multirow[t]{5}{*}{1.72} & \multirow[t]{5}{*}{0.12} \\
\hline & $21-30$ years & 3.29 & & \\
\hline & $31-40$ years & 3.12 & & \\
\hline & $41-50$ years & 2.88 & & \\
\hline & Above 51 years & 2.67 & & \\
\hline \multirow[t]{3}{*}{ Experience } & $0-5$ years & 3.31 & \multirow[t]{3}{*}{2.83} & \multirow[t]{3}{*}{0.45} \\
\hline & 6-11 years & 2.80 & & \\
\hline & More than 12 years & 2.47 & & \\
\hline \multirow[t]{3}{*}{ Designation } & Managers & 3.20 & \multirow[t]{3}{*}{8.65} & \multirow[t]{3}{*}{2.83} \\
\hline & Development officers & 3.20 & & \\
\hline & Supervisors & 3.19 & & \\
\hline
\end{tabular}

Table 13 : Authenticity and Individual based variations

\begin{tabular}{|c|c|c|c|c|}
\hline Variable & Category & Mean & t-value & Significance \\
\hline \multirow[t]{2}{*}{ Gender } & Male & 3.28 & \multirow[t]{2}{*}{3.54} & \multirow[t]{2}{*}{2.93} \\
\hline & Female & 3.39 & & \\
\hline \multirow[t]{3}{*}{ Education } & Under Graduate & 2.83 & \multirow[t]{3}{*}{1.84} & \multirow[t]{3}{*}{0.03} \\
\hline & Graduate & 3.12 & & \\
\hline & Post-Graduate & 3.34 & & \\
\hline \multirow[t]{5}{*}{ Age } & Below 20 years & 3.42 & \multirow[t]{5}{*}{1.93} & \multirow[t]{5}{*}{0.07} \\
\hline & $21-30$ years & 3.64 & & \\
\hline & $31-40$ years & 3.15 & & \\
\hline & 41-50 years & 3.14 & & \\
\hline & Above 51 years & 3.00 & & \\
\hline \multirow[t]{3}{*}{ Experience } & $0-5$ years & 3.68 & \multirow[t]{3}{*}{2.18} & \multirow[t]{3}{*}{0.23} \\
\hline & 6-11 years & 3.37 & & \\
\hline & More than 12 years & 3.19 & & \\
\hline \multirow[t]{3}{*}{ Designation } & Managers & 3.30 & \multirow[t]{3}{*}{7.82} & \multirow[t]{3}{*}{6.93} \\
\hline & Development officers & 3.40 & & \\
\hline & Supervisors & 3.37 & & \\
\hline
\end{tabular}

Table 13 indicates variation in authenticity among the five variables. From above figures it is noted that with age and experience, transparency and open work culture in an organization increases. This is obvious from the stats that as an employee move further in his career, he becomes mature and aware of the reasons and rationale behind any decision or initiative he make. This understanding that comes from experience further enhances the adaptability among the employees and makes it easy for them to accept decisions taken by senior level management. Moreover, academic qualifications also increase the mean score of authenticity. 
Table 14 : Sense of community and Individual based variations

\begin{tabular}{|c|c|c|c|c|}
\hline Variable & Category & Mean & t-value & Significance \\
\hline \multirow[t]{2}{*}{ Gender } & Male & 2.12 & \multirow[t]{2}{*}{2.18} & \multirow[t]{2}{*}{0.19} \\
\hline & Female & 2.73 & & \\
\hline \multirow[t]{3}{*}{ Education } & Under Graduate & 2.34 & \multirow[t]{3}{*}{10.11} & \multirow[t]{3}{*}{4.03} \\
\hline & Graduate & 2.46 & & \\
\hline & Post-Graduate & 2.39 & & \\
\hline \multirow[t]{5}{*}{ Age } & Below 20 years & 2.19 & \multirow[t]{5}{*}{1.10} & \multirow[t]{5}{*}{0.13} \\
\hline & $21-30$ years & 2.34 & & \\
\hline & $31-40$ years & 2.26 & & \\
\hline & $41-50$ years & 2.44 & & \\
\hline & Above 51 years & 2.56 & & \\
\hline \multirow[t]{3}{*}{ Experience } & $0-5$ years & 2.32 & \multirow[t]{3}{*}{2.08} & \multirow[t]{3}{*}{0.15} \\
\hline & 6-11 years & 2.40 & & \\
\hline & More than 12 years & 2.574 .933 .94 & & \\
\hline \multirow[t]{3}{*}{ Designation } & Managers & 2.22 & & \\
\hline & Development officers & 2.46 & & \\
\hline & Supervisors & 2.30 & & \\
\hline
\end{tabular}

Table 14 is to understand the variations based upon the forth construct of workplace spirituality. In Indian insurance companies, female employees with a mean of 2.73 score comparatively higher than their male (mean=2.12) counterparts. So, it can be concluded that women are more sociable. And findings also stats that with age and experience, Interconnectedness and interdependence among employees accelerates.

Table 15 : Lokasangraha and individual based variations

\begin{tabular}{|c|c|c|c|c|}
\hline Variable & Category & Mean & t-value & Significance \\
\hline \multirow[t]{2}{*}{ Gender } & Male & 2.32 & \multirow[t]{2}{*}{3.92} & \multirow[t]{2}{*}{2.83} \\
\hline & Female & 2.14 & & \\
\hline \multirow[t]{3}{*}{ Education } & Under Graduate & 2.33 & \multirow[t]{3}{*}{6.73} & \multirow[t]{3}{*}{5.94} \\
\hline & Graduate & 1.93 & & \\
\hline & Post-Graduate & 2.19 & & \\
\hline \multirow[t]{5}{*}{ Age } & Below 20 years & 2.39 & \multirow[t]{5}{*}{4.68} & \multirow[t]{5}{*}{3.71} \\
\hline & $21-30$ years & 2.10 & & \\
\hline & $31-40$ years & 2.13 & & \\
\hline & $41-50$ years & 2.43 & & \\
\hline & Above 51 years & 2.10 & & \\
\hline \multirow[t]{3}{*}{ Experience } & $0-5$ years & 2.18 & \multirow[t]{3}{*}{2.84} & \multirow[t]{3}{*}{1.74} \\
\hline & 6-11 years & 2.22 & & \\
\hline & More than 12 years & 2.15 & & \\
\hline \multirow[t]{3}{*}{ Designation } & Managers & 2.13 & \multirow[t]{3}{*}{5.84} & \multirow[t]{3}{*}{4.03} \\
\hline & Development officers & 2.12 & & \\
\hline & Supervisors & 2.32 & & \\
\hline
\end{tabular}

Table 15 represents the deviation in the last construct of workplace spirituality that is Lokasangraha. It is noteworthy to say that none of the demographic variable has the potential to deviate Lokasangraha. 


\section{CONCLUSION}

Hence, workplace management for employee engagement and work motivation are the three important components of workplace management. Findings are mainly intended to focus upon this issue by exploring the connection between workplace spirituality and these three constructs. Results establishes workplace spirituality as a necessary determinant of managerial effectiveness, employee engagement and work motivation. It is noted statistically that it is not possible to gain effectiveness, engagement and motivation without practicing workplace spirituality. Above study is probably the first one to apply necessary condition analysis at workplace spirituality. Institutionalize workplace spirituality at work will help employees to adhere the true meaning of their dharma, experience community feeling and understand interconnectedness. All these are to increase productivity at workplace. The above-mentioned theory also highlights one more ancient dimension of Indian spiritual values that is Karma Theory. However, the philosophy of Karma theory has been a part of all Indian scriptures always but somehow modern researches has no empirical investigation around it. Also, it is important to mention that in India meaning of spirituality is incomplete without a mention of Karma theory.

Beyond its unique findings and methodologies, this paper also has some limitations. Firstly, the samples collected for the city are not from around the world and limited to only NCR regions of India that's why generalization of the findings cannot be done. Secondly, the sample size is extremely large that have made the study more worthwhile. Lastly, present work used cross-sectional approach. Hence, results of present studies can be confirmed through any longitudinal explanation. Researchers can further elaborate spirituality by conceptualizing workplace using both qualitative and quantitative approach. Furthermore, researchers can also explore spirituality with the integration of different topics like employee attitude, organizational commitment, engagement etc. This re-exploration can lead to some new and exciting research that is beneficial for both individuals and organizations. Additionally, the methodology used in this research can be repeated in other cultures but with different dimensions of spirituality.

\section{REFERENCES}

\section{Books}

1) Armstrong Michael, A Handbook of Human Resource Management Practice, Kogan Page; 9 editions, 3 September 2003

2) Noe Raymond Andrew, John R. Hollenbeck, Barry Gerhart, Patrick M. Wright, Human

3) Resource management, McGraw-Hill Higher Education; 7 edition, 1 July 2010

4) Taylor Stephen, Carol Woodhams, Studying Human Resource Management, CIPD - Kogan Page; 2 edition, 24 May 2016

\section{Research Papers}

1. Nandi. Rahul, Effective Induction for employees' Performance and Satisfaction, International Journal of English Language, Literature and Humanities,3 (4), 2015

2. Alberta Nyavor, the Effect of Employee orientation on performance in the Ghana education service: A case of greater Accra region, Journal of Management 9(3), 219-232, 2012.

3. Hendricks Kenrick, A theory evaluation of an induction programme, Organizational Behaviour and Human Performance, 4(2): 142-75, 2012.

4. Ayeni, C.O.\& Popoola, S. O. Work Motivation, Job Satisfaction, and Organizational Commitment of Library Personnel in Academic and Research Libraries in Oyo State, Nigeria, Library Philosophy and Practice 2007.

5. Baker, D., Grenberg, C.\& Hemingway, C. What happy Companies know. Pearson Education Inc., Upper Saddle River, NJ., 2006

6. Barling, J., Weber, T. \&Kelloway,E.K Effects of transformational leadership training on attitudinal\& financial outcomes: A field experiment. Journal of Applied Psychology, 
81(6): 827-832, 2008

7. Okpara, J. O. Job Satisfaction and Organizational Commitment: Are there Differences Between American and Nigerian Managers Employed in the US MNCs in 2009 Nigeria? Library Philosophy and Practice 2007.

8. Academy of Business \& Administrative Sciences, Briarcliff College, Switzerland. Plakoyiannaki, E., Tzokas, N., Dimitratos, P. \& Saren, M. How Critical is Employee Orientation for Customer Relationship Management? Insights 120 Junfeng
Zhang from a Case Study, Journal of Management Studies 45(2), 268-293, 2008

9. Prahalad, C. K. \& Hamel, G. The Core Competence of the Corporation, Harvard Business Review, 68 (3), 79-91., 2005

10. Khurram, S., Sajid, B., \& Ramay, M. I. (2008). Impact of HRM Practices on Perceived performance of University Teachers in Pakistan. International Review of Business Research Papers, 4(2), 302-315.2007 